\title{
PENDEKATAN SAINTIFIK DALAM \\ PELAKSANAAN BIMBINGAN KLASIKAL OLEH GURU BIMBINGAN DAN KONSELING DI SEKOLAH
}

\author{
Sarleni Rhepon \\ Email: 1henie_87@yahoo.com \\ SMK N 4 Kepahiang
}

\begin{abstract}
Abstrak
Bimbingan klasikal merupakan bentuk dari layanan dasar pada bimbingan dan konseling. Bimbingan klasikal berupa pemberian informasi kepada siswa yang diberikan oleh guru bimbingan dan konseling. Masih terdapat guru bimbingan dan konseling dalam melaksanakan bimbingan klasikal menggunakan pendekatan yang konvensional, sehingga siswa merasa jenuh atau bosan. Oleh karena itu, guru bimbingan dan konseling perlu menggunakan pendekatan secara saintifik, agar siswa semangat mengikuti kegiatan dan memahami materi layanan. Sehingga siswa memperoleh pemahaman baru yang berguna bagi dirinya dalam kehidupan sehari-hari.
\end{abstract}

Kata kunci: bimbingan klasikal, layanan informasi, pendekatan saintifik.

\section{PENDAHULUAN}

Sebagai sebuah layanan profesional, kegiatan layanan bimbingan dan konseling (BK) tidak bisa dilakukan secara sembarangan, namun harus berangkat dan berpijak dari suatu landasan, jenis layanan, fungsi dan asas-asas yang kokoh, yang didasarkan pada hasil-hasil pemikiran dan penelitian yang mendalam. Dengan adanya pijakan ini diharapkan pengembangan layanan BK, baik dalam tataran teoritik maupun praktek dapat semakin mantap dan bisa dipertanggungjawabkan, serta mampu memberikan manfaat besar bagi kehidupan, khususnya bagi subjek layanan yang disebut sebagai konseli.

Pemberi layanan BK disebut Guru BK atau Konselor di sekolah yang merupakan salah satu tenaga pendidik. Hal ini sesuai dengan kualifikasi pendidik yang telah dituangkan pada Undang-undang Republik Indonesia Nomor 20 Tahun 2003 tentang Sistem Pendidikan Nasional Pasal 1 ayat 6 bahwa, "Pendidik adalah tenaga kependidikan yang berkualifikasi sebagai guru, dosen, konselor, pamong belajar, widyaiswara, tutor, instruktur, fasilitator, dan sebutan lain yang sesuai dengan kekhususan nya, serta berpartisipasi dalam penyelenggaraan pendidikan". Hal ini menegaskan bahwa guru BK memang bekerja secara profesional di jalur pendidikan formal. Guru BK/konselor yang profesional yaitu pendidik profesional yang minimal berkualifikasi akademik Sarjana Pendidikan (S1) dalam bidang BK dan lulus pendidikan profesi guru 
$\mathrm{BK} /$ Konselor, atau guru BK yang berkualifikasi minimal Sarjana Pendidikan (S-1) dalam bidang BK dan bersertifikasi pendidik.

Menurut Peraturan Menteri Pendidikan dan Kebudayaan Republik Indonesia Nomor 111 tahun 2014, komponen program layanan BK meliputi layanan dasar, layanan peminatan dan perencanaan individual pada siswa di sekolah. Layanan dasar diartikan sebagai proses pemberian bantuan kepada seluruh konseli melalui kegiatan penyiapan pengalaman terstruktur secara klasikal atau kelompok yang dirancang dan dilaksanakan secara sistematis dalam rangka mengembangkan kemampuan penyesuaian diri yang efektif sesuai dengan tahap dan tugas-tugas perkembangan (Pedoman Bimbingan dan Konseling pada Pendidikan Dasar dan Pendidikan Menengah, 2016). Kegiatan layanan dasar yaitu asesmen kebutuhan, bimbingan klasikal, bimbingan kelompok, pengelolaan media informasi.

Bimbingan klasikal diberikan secara runtut dan terjadwal di kelas, dapat dilaksanakan jika guru BK mengampu jam klasikal secara terjadwal untuk masuk dalam kelas di sekolahnya. Bimbingan klasikal dapat berupa pemberian layanan informasi dengan arah perkembangan aspekaspek pribadi, sosial, belajar dan karier. Hal ini juga ditegaskan oleh Asosiasi Bimbingan dan Konseling Indonesia (2013) bahwa layanan informasi dapat membantu siswa untuk menerima dan memahami berbagai informasi berkenaan perkembangan diri, sosial, belajar, karier/ jabatan, dan pendidikan lanjutan secara terarah, objektif, dan bijaksana.

\section{PEMBAHASAN}

Bimbingan klasikal dilaksanakan secara tatap muka di kelas secara terstruktur dan terprogram secara berkelanjutan berupa assessment kebutuhan atau materi bidang layanan pribadi, belajar, sosial atau karier (Pedoman Bimbingan dan Konseling pada Pendidikan Dasar dan Pendidikan Menengah, 2016). Durasi bimbingan klasikal 2 x 40 menit untuk SMP/sederajat, dan $2 \times 45$ menit untuk SMA/K/sederajat. Bimbingan klasikal diberikan kepada siswa antara 20-35 orang, secara terjadwal dan langsung oleh guru BK kepada siswa/konseli.

Pada pelaksanaan bimbingan klasikal, guru BK dapat menyampaikan berbagai layanan informasi terkait pribadi, sosial, belajar, karier untuk pengembangan diri siswa. Tohirin (2007) mengemukakan pemberian layanan informasi oleh guru BK agar siswa dapat mengetahui dan menguasai berbagai informasi yang dimanfaatkan dalam kehidupan sehari-harinya. Senada dengan Richma (2015) bahwa layanan informasi itu penting diberikan pada siswa untuk memberi pemahaman baru dalam upaya menghadapi kesulitan untuk mengenal diri, merencanakan dan mengembangkan pola hidup yang baik dan mandiri. Melalui layanan informasi, siswa dapat menerapkan materi layanan untuk pertimbangan diri dalam membuat keputusan dalam hidupnya. 
Pelaksanaan bimbingan klasikal tidak hanya dengan metode ceramah atau mendongeng suatu fenomena saja, yang dapat membuat merasa jenuh bahkan tidak mendapatkan pemahaman baru dari proses pembelajaran. Namun, pelaksanaan bimbingan klasikal harus menggunakan pendekatan saintifik agar terdapat hubungan timbal balik antara guru BK dengan siswa untuk pemahaman barunya. Oleh karena itu, melalui pendekatan saintifik, guru BK dapat memanfaatkan waktu layanan dengan optimal.

Hal tersebut seperti yang telah dikemukakan oleh Emria (2016) bahwa secara umum layanan informasi pada bimbingan klasikal yang dilaksanakan oleh guru BK di salah satu sekolah kota Padang masih menggunakan metode ceramah dan rendahnya penggunaan teknologi, sehingga kegiatan dianggap kurang optimal. Oleh karena itu, perencanaan dalam pelaksanaan layanan perlu disusun secara matang, agar waktu yang tersedia dapat dimanfaatkan dengan baik. Sesuai dengan pendapat M.Ali (dalam Afrimadona, 2009) bahwa alokasi waktu yang disediakan untuk layanan klasikal harus digunakan sesuai dengan kondisi dan lama kegiatan pembahasan materi, agar tujuan pembelajaran tercapai.

Berbagai materi dapat disampaikan Guru BK sesuai kebutuhan masing-masing siswa yang diampu. Hal ini seperti yang dikemukakan oleh Prayitno \& Erman (2004) bahwa berbagai materi layanan yang akan diberikan pada siswa harus baru, menarik, bermanfaat, sesuai kebutuhan, jelas dan mudah dipahami. Penyampaian materi pula dengan sentuhan tingkat tinggi, tanpa harus siswa datang duduk diam mencacat dan akhirnya tidak mendapatkan apa-apa. Sehingga, siswa tidak memperoleh informasi baru atau tidak belajar sama sekali.

Pada pelaksanaan bimbingan klasikal dalam penyampaian materi layanan, guru BK dapat menerapkan pendekatan dan menggunakan berbagai media sesuai dengan materi layanan yang akan diberikan pada siswa. Sanjaya (2012) mengemukakan bahwa pendekatan digunakan untuk kesuksesan atau keberhasilan guru dalam menciptakan strategi pembelajaran, agar berbagai tujuan pembelajaran dapat tercapati. Pendekatan saintifik dapat dilakukan guru BK, merupakan serangkaian aktivitas pengumpulan data melalui observasi atau eksperimen, mengolah informasi atau data, menganalisis, kemudian menyimpulkan, dan mengkomunikasikan yang dilakukan siswa atas materi bahasan. Peran guru sebagai fasilitator, dan siswa yang lebih aktif memahami materi layanan. Kegiatan bimbingan klasikal juga menjadi aktif karena siswa sibuk membahas materi dengan rekan kelompoknya dan berlatih berani mengemukakan hasil diskusi pada forum kelas besar. Maka, guru BK hendaknya cermat memilih pendekatan sesuai dengan materi layanan yang akan diberikan pada siswa di kelas.

Pendekatan saintifik merupakan pendekatan ilmiah dalam pembelajaran yang menempatkan siswa menjadi subjek aktif dalam mengkonstruk pengetahuan baru atau memadukan pengetahuan sebelumnya 
(si manis, 2019, didownload dari http://www.pelajaran.co.id/2019/01/p engertian-pendekatan-saintifik-

karakteris tik-tujuan-prinsip-danlangkah-pendeka tan-saintifik.html). Pendekatan saintifik dinyatakan lebih efektif dalam pelaksanaan pembelajaran dibandingkan pendekatan konvensional. Melalui pendekatan saintifik, siswa melakukan serangkaian aktivitas pengumpulan data melalui observasi, menanya, eksperimen, mengolah informasi atau data, lalu mengkomunikasikan. Melalui pendekatan saintifik pada bimbingan klasikal, siswa diarahkan aktif dan berani mengemukakan hasil pengumpulan data kepada siswa lain dalam forum kelas.

Beberapa metode/pendekatan saintifik dapat dilakukan oleh guru BK di kelas, seperti small group discussion, discovery learning, cooperative learning, contextual teaching and learning, problem based learning, self directed learning, project based learning dan masih banyak lainnya (Riska, 2017). Berbagai metode tersebut telah diuji coba oleh beberapa peneliti untuk menyimpulkan keefektifan metode dalam pelaksanaan bimbingan klasikal. Sehingga guru BK tidak perlu ragu menerapkan beberapa pendekatan tersebut pada siswa di sekolah.

Ramtia (2015) menyampaikan bahwa secara umum pendekatan contextual teaching and learning lebih efektif untuk meningkatkan arah perencanaan karier siswa SMK, dibandingkan dengan metode konvensional (ceramah atau mendongeng). Sejalan dengan
Taniredja, Faridli, \& Harmianti (2013), bahwa contextual teaching and learning membantu guru $\mathrm{BK}$ mengait-ngaitkan materi layanan dengan situasi dunia nyata pada siswa seperti arah perencanaan karier siswa.

Afrizal (2015) mengemukakan layanan informasi dikombinasikan dengan metode ceramah, sosiodrama, dan diskusi efektif mengubah persepsi siswa tentang disiplin belajar. Artinya, metode ceramah tidak digunakan $100 \%$, namun diikuti dengan metode sosiodrama dan diskusi kelompok. Selanjutnya, Emria (2016) mengemukakan secara umum metode blended learning efektif untuk meningkatkan motivasi belajar siswa. Berikutnya Wahyuni (2017) mengemukakan pendekatan kooperatif window shopping mampu meningkatkan partisipasi siswa untuk mengikuti layanan BK secara klasikal.

Berbagai pendekatan yang telah dilakukan tersebut, menegaskan guru BK mampu menggunakannya kepada siswa agar kegiatan layanan klasikal tidak terkesan monoton, namun sangat menarik untuk diikuti. Seperti yang disampaikan Rahmaniah (2013) bahwa layanan informasi tentang karier berkontribusi sebanyak 12,3\% terhadap arah perencanaan karier siswa SMA.

Selanjutnya Tohirin (2007) mengemukakan dalam penyampaian informasi, guru BK dapat menggunakan media video sebagai alat bantu berupa peraga animasi. Media video merupakan salah satu model pembelajaran yang inovatif, karena sesuai dengan perkembangan teknologi saat ini. Sehingga melalui pendekatan saintifik dengan 
penggunaan media, siswa dapat mengikuti kegiatan bimbingan klasikal dengan aktif dan menyenangkan, serta memperoleh pemahaman baru.

Seperti yang telah disampaikan oleh Mirnayenti (2015) bahwa penggunaan media animasi pada layanan informasi dapat meningkatkan sikap anti bullying siswa. Oleh karena itu, menggunakan media animasi diperkirakan sebagai solusi cerdas untuk guru BK yang akan menyampaikan materi yang luas dengan keterbatasan waktunya di kelas. Sehingga, media sangat bermanfaat untuk memperjelas penyajian materi agar tidak bersifat verbal, mengatasi keterbatasan ruang, waktu dan daya indera, serta mampu mengatasi sikap pasif siswa (Sadiman, Rahardjo \& Haryono, 2011).

\section{Berdasarkan}

pemaparan tersebut, penulis dapat memberikan beberapa contoh topik layanan bimbingan klasikal sesuai dengan pendekatan saintifik. Seperti topik "hentikan perundungan/bullying", "percaya diri" menggunakan small group discussion. Selanjutnya topik "bahaya merokok", "bahaya narkoba", "dampak gadget", "masa remaja dan perubahannya" menggunakan pendekatan discovery learning. Topik " manajemen waktu", "pengendalian emosi marah" menggunakan pendekatan self directed learning. Topik "stop mencontek", "dampak pergaulan bebas", "pernikahan dini" menggunakan problem base learning. Topik "pemanasan global", "pola hidup sehat" menggunakan pendekatan contextual teaching learning.

Berbagai topik layanan disusun dalam rencana pelaksanaan layanan bimbingan dan konseling (RPLBK). Pengembangan RPLBK bimbingan klasikal sesuai dengan tema/topik dan sistematika yang diatur dalam panduan penyelenggaraan layanan BK pada satuan pendidikan. Selanjutnya pada RPLBK bimbingan klasikal pada tahap pelaksanaan kegiatan harus sesuai sintak/langkahlangkah pendekatan yang digunakan.

Pada penyampaian materi dalam layanan klasikal, guru BK perlu membangun relasi sosial pada siswa. Hal ini karena setiap siswa itu unik dan berbeda dalam menyikapi setiap perilakunya. Prayitno (2009) mengemukakan guru BK perlu memiliki kewibawaan pada dirinya. Kewibawaan ini merupakan suatu kepribadian yang dimiliki seseorang yang timbul dari cara berpikir, merasa, bersikap dan bertingkah laku yang mempengaruhi dan menarik perhatian orang lain. Melalui kewibawaan yang tinggi, maka guru BK mampu menyampaikan berbagai materi dan diterima oleh siswa di kelas.

\section{KESIMPULAN}

Layanan informasi yang dilaksanakan guru BK di kelas dapat mempengaruhi tatanan atau pola hidup siswa menjadi pribadi yang mandiri. Guru BK perlu memilih media, metode/pendekatan sesuai dengan materi yang akan diberikan, agar siswa memahami bahasan dengan penuh semangat. Guru BK perlu terampil menggunakan 
pendekatan saintifik pada pelaksanaan layanan klasikal.

\section{REFERENSI :}

Afrimadona. 2009. Pendapat Siswa tentang Penyelenggaraan Layanan Informasi untuk Mempersiapkan Diri Memasuki Perguruan Tinggi. Skripsi tidak diterbitkan. BK UNP Padang.

Afrizal, S. 2015. Efektivitas Layanan Informasi yang Mengkombinasikan Metode Ceramah, Sosiodrama, dan Diskusi dalam Merubah Persepsi Siswa Tentang Disiplin Belajar. Jurnal Ilmiah Konseling: Volume 4 Number 1 March 2015.

Asosiasi Bimbingan dan Konseling Indonesia. 2013. Panduan Umum Pelayanan Bimbingan dan Konseling.

Emria, F. 2016. Efektivitas Layanan Informasi dengan Menggunakan Metode Blended Learning untuk Meningkatkan Motivasi Belajar. Jurnal Psikologi Pendidikan \& Konseling: Volume 2 Nomor 2 Juni 2016, Hal 84-92.

Kementerian Pendidikan dan Kebudayaan Direktorat Jenderal Guru dan Tenaga Kependidikan. 2016. Pedoman Bimbingan dan Konseling pada Pendidikan Dasar dan Pendidikan Menengah. Jakarta: Kemendikbud DirjenGTK. Mirnayenti. 2015. Efektivitas Layanan Informasi Menggunakan Media Animasi Meningkatkan Sikap Anti Bullying Peserta Didik. Jurnal Ilmiah Konseling: Volume 4 Number 2 June 2015.
Peraturan Menteri Pendidikan dan Kebudayaan Republik Indonesia Nomor 111 tahun 2014 tentang Bimbingan dan Konseling Pada Pendidikan Dasar dan Pendidikan Menengah.

Prayitno dan Erman Amti. 2004. Dasar-Dasar Bimbingan dan Konseling. Jakarta: Departemen Pendidikan dan Kebudayaan.

Prayitno. 2009. Dasar Teori dan Praksis Pendidikan. Padang: UNP Press.

Rahmaniah, A. 2013. "Kontribusi Layanan Informasi dan Layanan Penempatan/Penyaluran terhadap Perencanaan Karier Siswa". Tesis tidak diterbitkan. Padang: Prodi S2 BK FIP UNP.

Ramtia, D.P. 2015. Efektivitas Layanan Informasi dengan Pendekatan Contextual Teaching And Learning dalam Meningkatkan Arah Perencanaan Karier Siswa $S M K$. Jurnal Ilmiah Konseling: Volume 4 Number 3 September 2015.

Richma, H. 2015. Layanan Informasi Karir Membantu Peserta Didik Dalam Meningkatkan Pemahaman Karir. Jurnal Konseling Gusjigang: Vol 1 No 1 Tahun 2015.

Riska, A. 2017. Buku Ajar Konseling Klasikal. Padang: Sukabina Press.

Sadiman, Rahardjo dan Haryono. 2011. Media pendidikan. Jakarta: Persada.

Sanjaya, W. 2012. Strategi Pembelajaran. Jakarta: Kencana Prenada Media Group.

Si Manis. 2019. Pengertian Pendekatan Saintifik, 
Karakteristik, Tujuan, Prinsip dan Langkah Pendekatan Saintifik Lengkap. Di Download dari http://www.pelajaran.co.id/ 2019/01/pengertian-pendekatansaintifik-karakteristik-tujuanprinsip-dan-langkahpendekatan-saintifik.html. Tanggal 17-10-2019.

Taniredja, T., Faridli, E. M., \& Harmianti, S. 2013. Modelmodel Pembelajaran Inovatif dan Efektif. Bandung: Alfabeta.

Tohirin. 2007. Bimbingan dan Konseling di Sekolah Madrasah (Berbasis Integrasi). Jakarta: PT Raja Grasindo Persada.

Undang-undang Republik Indonesia Nomor 20 Tahun 2003 tentang Sistem Pendidikan Nasional.

Wahyuni, R. 2017. Pengaruh Penggunaan Metode Kooperatif Window Shopping terhadap Partisipasi Bimbingan Konseling Klasikal. Jurnal Penelitian Pendidikan Indonesia (JPPI): Vol 2 No. 2 April 2017. 